\title{
Pengaruh Capital Structure, Institutional Ownership, Dan Managerial Ownership Terhadap Profitabilitas Perusahaan Manufaktur
}

\author{
Sapto Bayu Aji ${ }^{1)}$, Djasmanuddin ${ }^{2}$, Andriono ${ }^{3)}$ \\ Akademi Akuntansi YKPN Yogyakarta \\ 1)Email:saptobayuaji@aaykpn.ac.id. \\ ${ }^{2) E m a i l: d j a s . a a y k p n @ g m a i l . c o m}$ \\ 3)Email:andri.hot@gmail.com
}

\begin{abstract}
Profitability is the end result of a number of company management policies and decisions (Brigham et al., 2001). This study aims to examine the effect of capital structure, institutional ownership, and managerial ownership on company profitability. Capital structure proxied by Debt to Equity Ratio (DER). The company's profitability is proxied by Return on Equity (ROE). The data used are the financial statements of manufacturing companies on the IDX from 2014 - 2018, the results of this study found that capital structure, institutional ownership, and managerial ownership have a positive effect on profitability.
\end{abstract}

Key Words: capital structure, institutional ownership, managerial ownership, profitability.

\section{A. PENDAHULUAN}

Industri manufaktur mempunyai peranan penting dalam memenuhi kebutuhan masyarakat. Hal tersebut menyebabkan banyak perusahaan manufaktur saling berkompetisi untuk mendapatkan, menjaga, dan meningkatkan segmen pasarnya. Kompetisi tersebut menuntut perusahaan yang bergerak di industri manufaktur untuk selalu meningkatkan inovasi dan ritme kinerja agar tujuan perusahaan dalam memperoleh keuntungan dapat tercapai. Sebagian besar perusahaan manufaktur yang ada di Indonesia telah go public. Salah satu tujuan perusahaan yang telah go public adalah memakmurkan para pemilik saham dengan selalu berupaya meningkatkan profitabilitas. Dilihat dari sudut pandang manajemen keuangan, peningkatan profitabilitas perusahaan akan sangat membantu dalam memaksimalkan kesejahteraan pemilik (shareholder). Profitabilitas merupakan kemampuan dalam memperoleh laba yang diukur menggunakan persentase yang digunakan untuk menilai sejauh mana perusahaan mampu menghasilkan keuntungan.

Permasalahan penting yang dihadapi manajer dalam mengelola perusahaan guna memperoleh profit dan meningkatkan kekayaan pemegang saham adalah masalah pendanaan. Peranan manajemen perusahaan dalam menentukan capital structure 


\section{Sapto Bayu Aji, Djasmanuddin, Andriono}

(struktur modal) optimal merupakan salah satu tugas utama yang sangat penting, karena hal itu sangat terkait dengan keberlangsungan perusahaan di masa mendatang. Struktur modal perusahaan dapat diperoleh dari pihak internal dan eksternal perusahaan. Struktur modal adalah perimbangan antara modal eksternal atau liabilitas dengan modal internal. Liabilitas terbagi menjadi dua, yaitu short-term debt (liabilitas jangka pendek) dan long-term debt (liabilitas jangka panjang).

Penggunaan liabilitas sebagai sumber pendanaan eksternal mempunyai konsekuensi posistif (keuntungan) dan konsekuensi negatif (kerugian). Keuntungan menggunakan pendanaan liabilitas didapatkan dari pengenaan pajak, dimana bunga dari liabilitas merupakan pengurangan pajak, dan meningkatnya kedisiplinan manajer yang dituntut untuk dapat membayar semua liabilitas, sedangkan kerugiannya berhubungan dengan munculnya biaya pengelolaan (keagenan) dan biaya kebangkrutan. Melalui kebijakan struktur modal yang optimal, maka akan dicapai profitabilitas yang maksimal. Salah satu penelitian di India yang dilakukan oleh Singh dan Bagga (2019) menemukan bahwa struktur modal berpengaruh positif terhadap profitabilitas perusahaan.

Salah satu isu yang paling penting dalam perusahaan go public adalah masalah struktur kepemilikan saham yang terkait dengan peningkatan kinerja perusahaan. Wahyudi dan Pawesti (2006) mengemukakan bahwa nilai perusahaan dipengaruhi oleh jalannya kinerja perusahaan yang baik, jalannya kinerja perusahaan yang baik dipercaya oleh beberapa peneliti dipengaruhi oleh struktur kepemilikan saham perusahaan.

Menurut Wiranata dan Nugrahanti (2013), Indonesia memiliki karakteristik struktur kepemilikan yang berbeda dari perusahaan di negara lain. Di Indonesia sebagian besar para pendiri perusahaan duduk sebagai dewan direksi atau dewan komisaris. Keadaan itulah yang menimbulkan konflik keagenan antara manajer dan pemilik serta antara pemegang saham mayoritas dan minoritas. Seperti yang diungkapkan oleh Jensen \& Meckling (1976) bahwa munculnya konflik keagenan disebabkan adanya pemisahan antara kepemilikan dan pengelolaan perusahaan. Teori keagenan menjelaskan bahwa pihak-pihak yang terkait dalam perusahaan yakni manajer, pemilik perusahaan dan kreditor pada dasarnya mereka memiliki kepentingan yang berbeda. Penelitian sebelumnya mengenai institutional ownership (kepemilikan institusional) dan managerial ownership (kepemilikan manajerial) terhadap kinerja perusahaan pernah dilakukan oleh beberapa peneliti. Permanasari (2010) menemukan bahwa struktur kepemilikan institusional dan struktur kepemilikan manajerial berpengaruh positif terhadap profitabilitas perusahaan.

Mengingat profitabilitas merupakan variabel yang penting dan strategis bagi kelangsungan hidup perusahaan dan bagi peningkatan kekayaan pemilik, maka penulis termotivasi untuk melakukan penelitian mengenai profitabilitas perusahaan. Sebagaimana telah disampaikan bahwa, profitabilitas perusahaan tidak lepas atau terkait dengan struktur modal perusahaan dan struktur kepemilikan perusahaan. Artinya, secara konsepsi struktur modal dan struktur kepemilikan memiliki pengaruh terhadap profitabilitas yang diperoleh perusahaan. 


\section{Rumusan Masalah}

Berdasarkan uraian di atas yang telah disampaikan, peneliti melihat terdapat suatu kebutuhan lebih lanjut untuk menguji pengaruh struktur modal, kepemilikan institusional, dan kepemilikan manajerial terhadap profitabilitas perusahaan. Oleh karena itu permasalahan dalam penelitian ini dapat dinyatakan sebagai berikut:

1. Apakah capital structure mempunyai pengaruh positif terhadap profitabilitas perusahaan?

2. Apakah institutional ownership mempunyai pengaruh positif terhadap profitabilitas perusahaan?

3. Apakah managerial ownership mempunyai pengaruh positif terhadap profitabilitas perusahaan?

\section{B. TINJAUAN LITERATUR}

\section{Capital Structure (Struktur Modal)}

Untuk menjaga jalannya perusahaan, kebutuhan akan modal sangat penting bagi perusahaan. Modal sangat dibutuhkan oleh perusahaan manapun, karena dengan adanya modal maka aktivitas perusahaan akan dapat berjalan, terutama untuk perusahaan manufaktur. Dibanding perusahaan non manufaktur atau perusahaan jasa, perusahaan manufaktur untuk selalu berusaha dalam mengembangkan produknya secara lebih cepat, yaitu dengan melakukan berbagai inovasi dan cenderung mempunyai ekspansi pasar yang lebih luas. Dikarenakan hal tersebut, maka perusahaan manufaktur harus menentukan seberapa besar modal yang dibutuhkan untuk membiayai pengembangan usahanya. Modal terdiri atas ekuitas (modal sendiri) dan liabilitas (debt). Menurut Husnan (2000) struktur modal adalah perbandingan liabilitas dan modal sendiri dalam struktur finansial perusahaan. Perbandingan antara liabilitas jangka panjang dengan modal sendiri adalah struktur modal yang merupakan bagian dari struktur keuangan perusahaan (Weston dan Copeland, 2010). Tidak berbeda jauh dengan Martono dan Harjito (2005) menyatakan: "Struktur modal merupakan perbandingan atau perimbangan dana jangka panjang perusahaan yang ditunjukkan oleh hutang jangka panjang terhadap modal sendiri. Pemenuhan modal sendiri berasal dari modal saham, laba ditahan, dan cadangan".

Dari uraian diatas, dapat disimpulkan bahwa struktur modal adalah perbandingan antara liabilitas dengan ekuitas yang digunakan perusahaan untuk mendanai aktivitasnya. Karena liabilitas dan ekuitas mempunyai konsekuensi finansial yang berbeda, maka pihak manajemen harus memahami dengan baik keduanya. Jika pendanaan dari modal sendiri masih kurang, maka perlu dipertimbangkan pendanaan yang berasal eksternal, yaitu dari liabilitas (debt financing).

Dalam teori struktur modal diasumsikan bahwa perubahan struktur modal berasal dari penerbit obligasi dan pembelian kembali saham biasa atau penerbitan saham baru. 


\section{Sapto Bayu Aji, Djasmanuddin, Andriono}

Teori-teori struktur modal antara lain:

\section{a. Signaling Theory}

Ketidaksesuaian informasi antara manajemen perusahaan dengan stakeholder ditunjukkan dalam teori sinyal. Teori sinyal membahas mengenai bagaimana sebaiknya perusahaan memberikan sinyal-sinyal kepada para pemakai laporan keuangan.

Suwardjono (2005) menyampaikan bahwa sinyal bisa didapatkan dari pengumuman yang dilakukan oleh suatu badan usaha yang memperjualbelikan surat berharga. Pengumuman tersebut pada akhirnya akan dapat mempengaruhi naik turunnya harga saham perusahaan.

Ross (1977) juga menyampaikan bahwa perusahaan cenderung akan mengkomunikasikan apapun yang terkait hasil kinerjanya kepada investor apabila perusahaan tersebut punya keyakinan mengenai prospek perusahaan ke depannya baik. Dengan kata lain, salah satu sinyal dari perusahaan yang mempunyai kualitas baik adalah cenderung akan menyampaikan laporan keuangannya sesuai dengan periode (waktu) yang seharusnya. Hal ini akan sangat sulit dapat dilakukan oleh perusahaan yang mempunyai kualitas buruk.

Pendapat dari pihak independen diperlukan untuk menilai laporan keuangan dari suatu perusahaan, hal ini dilakukan untuk memastikan stakeholder percaya terkait keandalan informasi laporan keuangan yang dipublikasikan oleh perusahaan (Jama'an, 2008). Pengelola perusahaan, pemilik perusahaan, dan pihak eksternal perusahaan akan sangat terbantu dengan adanya teori sinyal, karena ketidaksesuaian informasi yang kemungkinan terjadi dapat berkurang.

\section{b. Teori Keagenan (Agency Theory)}

Perusahaan merupakan organisasi legal yang berfungsi sebagai nexus (penghubung) dari hubungan kontrak antara para individu dalam perusahaan (Belkaoi, 2007). Suwardjono (2005) mengemukakan bahwa hubungan keagenan merupakan hubungan antara pemilik perusahaan dengan individu-individu yang mengelola perusahaan (manajer).

Manajer mempunyai kewajiban untuk memberikan laporan dan mempertanggungjawabkan semua usahanya kepada pemilik saham perusahaan, karena manajer adalah pihak yang diberi mandat oleh pemilik saham untuk bekerja demi kepentingan pemilik saham. Untuk itu manajemen yang diwakili oleh manajer diberi kewenangan untuk membuat dan mengambil kebijakan tertentu bagi kepentingan terbaik pemilik saham.

Adanya kemungkinan manajer tidak selalu menjalankan usaha seperti yang dikehendaki keinginan pemilik, maka hal tersebut akan menimbulkan konflik kepentingan antara pemilik saham (prinsipal) dan manajer (agen). Terjadinya konflik kepentingan tersebut disebut dengan konflik keagenan (agency conflict) (Belkaoi, 2007).

Konflik keagenan yang terjadi dapat mempengaruhi tingkat rasionalitas para investor. Konflik keagenan akan mengakibatkan adanya sifat opportunistic manajemen, 
yang nantinya akan mengakibatkan rendahnya kualitas laba. Para pemakai laporan keuangan seperti investor maupun kreditur akan melakukan kesalahan di dalam membuat keputusan jika kualitas laba yang dihasilkan rendah, yang pada akhirnya akan menurunkan nilai perusahaan (Siallagan dan Machfoedz, 2006).

\section{Struktur Kepemilikan}

Sujono dan Soebiantoro (2007) mengemukakan bahwa proporsi kepemilikan institusional dan kepemilikan manajemen dalam kepemilikan saham perusahaan merupakan struktur kepemilikan saham. Uraian mengenai struktur kepemilikan saham disampaikan sebagai berikut:

\section{a. Institutional Ownership (Kepemilikan Institusional)}

Kepemilikan institusional adalah kepemilikan saham perusahaan yang dimiliki oleh lembaga atau institusi di luar perusahaan. Dibandingkan pemilik saham individual, pemilik saham dari institusi luar perusahaan diyakini memiliki kemampuan lebih baik untuk mengawasi tindakan manajemen. Lembaga atau institusi di luar perusahaan yang memiliki saham relatif lebih cepat untuk mendeteksi adanya kesalahan yang terjadi, sehingga perilaku opportunistic dari manajer dapat segera dikendalikan atau dihalangi.

Penelitian Gultom dkk. (2013) mengemukakan bahwa pemilik saham institusional dengan kepemilikan saham yang besar, memiliki keinginan besar untuk memantau pengambilan keputusan perusahaan yang dilakukan oleh manajer. Kepemilikan saham institusional yang besar membuat semakin kuat suara untuk mendorong memaksimalkan kinerja perusahaan ke arah yang lebih baik dan menguntungkan.

Kecenderungan manajemen untuk menentukan kebijakan dalam membuat laporan keuangan dapat ditekan oleh kepemilikan institusional, sehingga laporan keuangan tersebut dapat memberikan infromasi terkait kualitas laba yang dilaporkan dapat dipertanggungjawabkan (Winarto, 2015). Dengan kepemilikan persentase saham institusional tertentu maka dapat mengawasi dan mengendalikan tindakan penyimpangan dalam proses pembuatan laporan keuangan.

\section{b. Managerial Ownership (Kepemilikan Manajerial)}

Saham yang dimliki oleh manajemen perusahaan disebut juga kepemilikan saham manajerial. Hal ini sama dengan yang disampaikan oleh Satmoko dan Sudarman (2011) bahwa kepemilikan saham dari manajemen yang aktif ikut serta dalam pengambilan keputusan di perusahaan itulah yang dikatakan kepemilikan menajemen (manajerial).

Kepemilikan manajemen yang meningkat di suatu perusahaan akan memunculkan suatu pemikiran bahwa nilai perusahaan juga akan meningkat. Hal ini dapat dimengerti karena manajemen akan berusaha semaksimal mungkin untuk mengelola perusahaan dengan baik yang pada akhirnya kinerja keuangan perusahaan meningkat, sehingga nilai perusahaan juga secara tidak langsung akan meningkat. Oleh karena itu maka operasional perusahaan akan efektif apabila kepemilikan saham yang dimiliki manajemen besar. 


\section{Sapto Bayu Aji, Djasmanuddin, Andriono}

Penelitian Brigham dan Houston (2001) menemukan bahwa kepemilikan manajerial yang meningkat akan meningkatkan nilai perusahaan. Penelitian tersebut menguji keterkaitan hubungan antara komposisi dewan komisaris dan kepemilikan manajerial terhadap nilai perusahaan. Tambunan (2015) menyampaikan bahwa manajemen akan berusaha semaksimal mungkin untuk meningkatkan kinerjanya untuk kepentingannya maupun untuk kepentingan pemilik saham apabila kepemilikan manajemen dalam jumlah besar. Nilai perusahaan akan meningkat apabila kinerja dari manajemen dilakukan secara optimal.

\section{Profitabilitas}

Hasil akhir dari sejumlah rangkaian kegiatan dan keputusan yang dilakukan oleh manajemen itulah yang dinamakan profitabilitas (Brigham et al., 2001). Profitabilitas menurut Petronila dan Mukhlasin (2003) adalah gambaran hasil kinerja dari manajemen dalam mengelola perusahaan. Dari definisi tersebut dapat dirangkum bahwa profitabilitas adalah hasil dari aktivitas pengelolaan perusahaan selama periode waktu tertentu.

Menurut Horne dan Wachowicz (2005) rasio profitabilitas terdiri atas dua jenis yaitu rasio profitabilitas kaitannya dengan penjualan ( $G P M, O P M$, dan $N P M)$, dan profitabilitas kaitannya dengan investasi ( $R O A$ dan $R O E$ ). Perusahaan yang mempunyai prospek baik, biasanya stabil memperoleh profitabilitas yang tinggi, secara tidak langsung hal tersebut akan meningkatkan nilai perusahaan dan pada akhirnya akan mendapatkan respon positif dari investor. Dari sudut pandang investor, semakin besar laba yang diperoleh perusahaan, maka kemungkinan akan semakin besar pula return yang akan diterima.

Proxi yang digunakan untuk mewakili profitabilitas dalam penelitian ini adalah return on equty (ROE). ROE merupakan rasio yang membandingkan laba bersih dengan ekuitas saham biasa. Semakin besar nilai ROE maka semakin besar kemungkinan pengembalian yang akan diterima oleh investor yang berinvestasi, begitu pula sebaliknya.

\section{Pengembangan Hipotesis}

\section{Pengaruh struktur modal terhadap profitabilitas}

Struktur modal dalam penelitian ini diproxikan dengan rumus Debt to Equity Ratio (DER). Semakin kecil nilai DER yang dihasilkan, maka kemampuan ekuitas untuk menjamin liabilitas yang dimiliki perusahaan semakin besar. Dengan kata lain, ekuitas yang dimiliki perusahaan mampu untuk membackup liabiltas yang ada.

Penelitian Rosalia dan Budiyanto (2018) menunjukkan bahwa struktur modal mempunyai pengaruh negatif terhadap profitabilitas perusahaan. Argumen dalam penelitian ini adalah liabilitas perusahaan yang tinggi akan menyebabkan beban yang harus dibayarkan (pokok dan bunga) akan semikin besar, sehingga profitabilitas perusahaan akan turun. Penelitian tersebut bertentangan dengan penelitian yang dilakukan oleh Singh dan Bagga (2019), Fauzan dan Mukaram (2017) serta Kusumajaya 
(2011), yang menemukan pengaruh positif signifikan terhadap profitabilitas. Dengan kata lain, tiga penelitian tersebut mengungkapkan bahwa perusahaan dengan hasil DER yang tinggi, maka akan semakin tinggi profitabilitas yang akan diperoleh perusahaan. Oleh karena itu dalam penelitian ini dapat dihipotesiskan sebagai berikut:

$\mathrm{H}_{\mathrm{a} 1}$ : Struktur modal berpengaruh positif terhadap profitabilitas perusahaan.

\section{Pengaruh struktur kepemilikan terhadap profitabilitas}

Penelitian yang dilakukan Siallagan dan Machfoedz (2006) mengungkapkan bahwa adakalanya para manajer melakukan tindakan yang tidak sesuai dengan harapan dan keinginan pemilik, hal ini disebabkan karena adanya pemisahan kepemilikan yang memunculkan konflik dalam pengendalian dan pelaksanaan operasional perusahaan, konflik yang muncul ini disebut dengan konflik keagenan. Menurut Ismiyanti dan Mamduh (2003) mengatakan bahwa meningkatnya pengawasan pihak diluar perusahaan, salah satunya disebabkan adanya kepemilikan institusional yang tinggi. Adanya pengawasan pihak eksternal maka aktivitas operasional perusahaan dapat lebih terpantau sehingga tujuan perusahaan dapat tercapai. Hal ini seperti yang dikatakan Slovin dan Sushka (1993) apabila institusi mampu menjadi alat monitoring yang efektif maka nilai perusahaan dapat meningkat.

Penelitian yang dilakukan oleh Wiranata dan Nugrahanti (2013) menemukan bahwa kepemilikan institusional dan kepemilikan manajerial tidak berpengaruh terhadap profitabilitas perusahaan manufaktur. Hasil ini berbeda dengan penelitian yang dilakukan Wahyudi dan Pawestri (2006), penelitian ini menemukan bahwa kepemilikan manajerial berpengaruh terhadap nilai perusahaan. Hasil peneltian tersebut realtif sejalan dengan penelitian Iturriaga dan Sanz (1998) yang mengatakan bahwa hubungan struktur kepemilikan manajerial dengan nilai perusahaan merupakan hubungan yang sangat erat. Adanya insentif yang diterima manajer maka para manajer berusaha untuk mensejajarkan kepentingannya dengan pemilik saham dari luar perusahaan dengan cara kepemilikan saham manajerial lebih ditingkatkan atau lebih diperbanyak lagi. Jensen dan Meckling (1976) mengatakan peningkatan kepemilikan saham oleh manajemen merupakan salah satu cara untuk mengurangi agency cost.

Kepemilikan manajerial akan mensejajarkan kepentingan manajemen dan pemilik saham di luar perusahaan, sehingga kebijakan maupun keputusan apapun yang dilakukan oleh manajer merupakan suatu resiko yang harus siap diterima dengan penuh tanggungjawab. Apabila suatu keputusan akan menghasilkan keuntungan maka manfaatnya akan dapat langsung diperoleh, namun apabila mendapatkan kerugian maka itu merupakan konsekuensi yang harus diterima. Pernyataan tersebut menegaskan bahwa proporsi kepemilikan manajemen yang semakin besar dalam perusahaan, maka manajemen cenderung akan lebih optimal menjalankan operasional perusahaan untuk kepentingan pemegang saham yang termasuk didalamnya adalah dirinya sendiri.

Penelitian Gultom dkk. (2013) menyatakan bahwa kepemilikan saham institusional yang besar memiliki dorongan yang kuat untuk memantau pengambilan 
keputusan dalam perusahaan. Kepemilikan saham institusional relatif lebih efektif untuk mengawasi kinerja dari manajemen perusahaan sehingga nantinya profitabilitas perusahaan dapat ditingkatkan. Disamping itu, pemilik saham institusional akan selalu berusaha melakukan monitoring, pembandingan dan evaluasi dari usaha yang dijalankan dengan perusahaan yang dimiliki sahamnya sehingga nilai perusahaan miliknya juga akan tetap terjaga.

Didasarkan uraian yang telah tersampaikan di atas maka diajukan hipotesis sebagai berikut:

$\mathrm{H}_{\mathrm{a} 2}$ : Kepemilikan institusional berpengaruh positif terhadap profitabilitas perusahaan.

$\mathrm{H}_{\mathrm{a} 3}$ : Kepemilikan manajerial berpengaruh positif terhadap profitabilitas perusahaan.

Berdasarkan rumusan masalah dan hipotesis penelitian ini maka dapat disusun model penelitian atau kerangka pemikiran sebagai berikut:

\section{METODE PENELITIAN}

\section{Populasi dan sampel}

Populasi penelitian ini adalah seluruh perusahaan manufaktur yang terdaftar di Bursa Efek Indonesia (BEI). Sampel penelitian ini adalah sebagian dari anggota populasi. Pengambilan sampel secara purposive sampling, dengan kriteria: (1) terdaftar di BEI berturut-turut selama tahun 2014-2018, (2) laporan keuangan tahunan auditan dapat diakses secara langsung selama tahun 2014-2018.

\section{DEFINISI OPERASIONAL VARIABEL}

\section{Profitabilitas perusahaan}

Profitabilitas adalah kemampuan perusahaan menghasilkan profit atau laba. Pengukuran profitabilitas dalam penelitian ini menggunakan rasio antara laba bersih yang diperoleh perusahaan dengan modal sendiri (ekuitas) yang digunakan (ROE).

\section{Struktur modal (Capital Structure)}

Struktur modal adalah komposisi modal perusahaan yang terdiri atas modal asing (hutang) dan modal sendiri. Dalam penelitian ini struktur modal diukur dengan rasio antara total liabilitas perusahaan dengan modal sendiri (ekuitas) yang digunakan (DER).

\section{Kepemilikan Institusional (Institutional Ownership)}

Kepemilikan institusional (KI) diukur dengan persentase jumlah saham yang 
dimiliki oleh investor institusional dibandingkan dengan jumlah total saham yang diinformasikan dalam laporan keuangan. Kepemilikan institusional dihitung dengan menggunakan formula sebagai berikut (Pancawati, 2009):

$\mathrm{KI}=$ Jumlah saham yang dimiliki institusi/Jumlah total saham

\section{Kepemilikan Manajerial (Managerial Ownership)}

Kepemilikan manajerial (KM) diukur dengan persentase jumlah saham yang dimiliki oleh manajemen dibandingkan dengan jumlah total saham yang diinformasikan dalam laporan keuangan. Kepemilikan manajerial dihitung dengan menggunakan formula sebagai berikut (Pancawati, 2009):

$\mathrm{KM}=$ Jumlah saham yang dimiliki manajamen/Jumlah total saham

\section{Data dan Sumber Data}

Seluruh data yang digunakan dalam penelitian ini adalah data sekunder, yaitu data yang telah tersedia atau telah ada. Sumber data yang digunakan adalah Laporan Keuangan Tahunan Auditan perusahaan sampel, yang dipublikasi oleh Bursa Efek Indonesia (BEI).

\section{Metode Analisis Data}

Metode analisis data dalam penelitian ini menggunakan analisis regresi berganda (multiple regression methode) dan pengolahan data melalui software SPSS. Untuk model penelitian ini dinyatakan dengan persamaan sebagai berikut:

$\mathrm{PP}=\mathrm{b}_{\mathrm{o}}+\mathrm{b}_{1} \mathrm{SM}+\mathrm{b}_{2} \mathrm{KI}+\mathrm{b}_{3} \mathrm{KM}+\mathrm{e}$

Keterangan:

$\mathrm{PP}=$ Profitabilitas perusahaan

$\mathrm{SM}=$ Struktur modal

$\mathrm{KI}=$ Kepemilikan institusional

$\mathrm{KM}=$ Kepemilikan manajerial

Model tersebut terlebih dahulu akan dilakukan uji asumsi klasik. Uji asumsi klasik diperlukan untuk memastikan bahwa data yang digunakan dalam penelitian ini layak (fit). Apabila suatu model regresi tidak lolos dari uji asumsi klasik maka koefisien regresi yang didapatkan bias sehingga dapat menimbulkan kesalahan dalam penerapannya. Oleh karena itu, suatu model regresi sebelum digunakan untuk mengambil keputusan terlebih dahulu harus dipastikan lolos dari uji asumsi klasik. Uji asumsi klasik teridiri atas: uji multikolinieritas, uji heteroskedastisitas, uji autokorelasi, dan uji normalitas (Widarjono, 2007). 


\section{HASIL ANALISIS DATA DAN PEMBAHASAN}

Obyek penelitian ini adalah perusahaan manufaktur yang terdaftar di BEI dari tahun 2014 - 2018. Berdasarkan pemilihan sampel dengan menggunakan metode purpose sampling diperoleh jumlah sampel sebanyak 68 perusahaan manufaktur dari 127 perusahaan. Total observasi yang digunakan dalam sampel perusahaan manufaktur sebanyak 264 observasi. Pengolahan data penelitian menggunakan software SPSS.

Berdasarkan hasil uji asumsi klasik terhadap model regresi penelitian ini, terlihat bahwa model regresi penelitian ini memenuhi syarat dari uji asumsi klasik. Dari terpenuhinya empat uji asumsi klasik maka parameter (koefisien regresi) yang dihasilkan tidak bias, sehingga layak digunakan dalam penelitian.

\section{Analisis regresi}

Hasil analisis regresi linier berganda dalam penelitian ini dapat dilihat dalam Tabel 4 berikut ini.

Tabel 4

Hasil Analisis Regresi Linier Berganda

\begin{tabular}{lcccc}
\hline \multicolumn{1}{c}{ Variabel Bebas } & $\begin{array}{c}\text { Koefisien } \\
\text { regresi } \\
(\mathrm{bi})\end{array}$ & $\begin{array}{c}\text { Koefisien } \\
\text { regresi } \\
\text { baku } \\
(\beta \mathrm{i})\end{array}$ & $\mathrm{t}_{\text {hitung }}$ & $\mathrm{p}$ \\
\hline Konstanta & $-140,039$ & & & \\
Struktur Modal (SM) & 30,266 & 0,311 & 50,444 & 0,000 \\
Kepemilikan Institusional (KI) & 0,264 & 0,206 & 30,587 & 0,000 \\
Kepemilikan Manajerial $(\mathrm{KM})$ & 70,947 & 0,150 & 20,664 & 0,008 \\
\hline Variabel dependen $=$ Profitabilitas Perusahaan $(\mathrm{PP})$ & & & \\
$\mathrm{N}=264 ; \mathrm{dw}=\mathrm{d}=1,995 ; \mathrm{R}^{2} \mathrm{adj}=0,178(17,8 \%)$ & & & \\
\hline
\end{tabular}

Sumber: Data sekunder diolah.

Berdasarkan ringkasan hasil analisis regresi linier berganda yang disajikan dalam Tabel 4, maka model regresi penelitian ini dapat ditulis sebagai berikut:

$$
\mathrm{PP}=-140,039+30,266 \mathrm{SM}+0,264 \mathrm{KI}+70,947 \mathrm{KM}
$$

Keterangan:

$\mathrm{PP}=$ Profitabilitas perusahaan diproxy dengan ROE

$\mathrm{SM}=$ Struktur modal yang diproxy dengan DER

$\mathrm{KI}=$ Kepemilikan institusional (\%)

$\mathrm{KM}=$ Kepemilikan manajerial $(\%)$ 


\section{Pengujian Hipotesis}

\section{Pengujian Hipotesis Pertama}

Hipotesis pertama penelitian ini menduga bahwa struktur modal berpengaruh positif terhadap profitabilitas perusahaan. Hipotesis pertama ini dapat diformulasikan sebagai berikut:

$\mathrm{Ha}_{\mathrm{o}}: \beta_{1}=0$ Struktur modal tidak berpengaruh terhadap profitabilitas perusahaan.

$\mathrm{Ha}_{1}: \beta_{1}>0$ Struktur modal berpengaruh positif terhadap profitabilitas perusahaan.

Dari hasil analisis regresi yang telah dilakukan, besarnya koefisien regresi baku variabel struktur modal $(\mathrm{SM})$ adalah $\beta_{1}=0,311$ dengan $\mathrm{p}=0,000$. Pada tingkat signifikansi $\alpha=0,05$ maka $p(0,000)<\alpha(0,05)$, sehingga koefisien regresi baku $\beta_{1}$ signifikan lebih besar dari nol. Dari hasil tersebut maka hipotesis nol $\left(\mathrm{H}_{\mathrm{ol}}\right)$ ditolak dan hipotesis alternatif $\left(\mathrm{H}_{\mathrm{a} 1}\right)$ diterima, dengan kata lain hipotesis pertama penelitian ini diterima. Hasil hipotesis pertama diterima berarti dapat disimpulkan bahwa struktur modal berpengaruh positif terhadap profitabilitas perusahaan. Hasil ini tidak mendukung penelitian yang dilakukan oleh Rosalia dan Budiyanto (2018), tetapi mendukung penelitian sebelumnya yang telah dilakukan oleh penelitian Kusumajaya (2011), Fauzan dan Mukaram (2017), serta mendukung penelitian setelahnya Singh dan Bagga (2019).

\section{Pengujian Hipotesis Kedua}

Hipotesis kedua penelitian ini menduga bahwa kepemilikan institusional berpengaruh positif terhadap profitabilitas perusahaan. Hipotesis pertama ini dapat diformulasikan sebagai berikut:

$\mathrm{H}_{\mathrm{o} 2}: \quad \beta_{2}=0$ Kepemilikan institusional tidak berpengaruh terhadap profitabilitas perusahaan.

$\mathrm{Ha}_{2}: \quad \beta_{2}>0$ Kepemilikan institusional berpengaruh positif terhadap profitabilitas perusahaan.

Dari hasil analisis regresi yang telah dilakukan, besarnya koefisien regresi baku variabel kepemilikan institusional (KI) adalah $\beta_{2}=0,206$ dengan $\mathrm{p}=0,000$. Pada tingkat signifikansi $\alpha=0,05$ maka $p(0,000)<\alpha(0,05)$, sehingga koefisien regresi baku $\beta_{2}$ signifikan lebih besar dari nol. Dari hasil tersebut maka hipotesis nol $\left(\mathrm{H}_{02}\right)$ ditolak dan hipotesis alternatif $\left(\mathrm{H}_{\mathrm{a} 2}\right)$ diterima, dengan kata lain hipotesis kedua penelitian ini diterima. Hasil hipotesis kedua diterima berarti dapat disimpulkan bahwa kepemilikan institusional berpengaruh positif terhadap profitabilitas perusahaan. Hasil ini tidak mendukung penelitian yang dilakukan oleh Wiranata dan Nugrahanti (2013), tetapi mendukung penelitian sebelumnya yang telah dilakukan oleh Permanasari (2010) dan Gultom dkk. (2013). 


\section{Sapto Bayu Aji, Djasmanuddin, Andriono}

\section{Pengujian Hipotesis Ketiga}

Hipotesis ketiga penelitian ini menduga bahwa kepemilikan manajerial berpengaruh positif terhadap profitabilitas perusahaan. Hipotesis kedua ini dapat diformulasikan sebagai berikut:

$\mathrm{H}_{\mathrm{o} 3}: \beta_{3}=0$ Kepemilikan manajerial tidak berpengaruh terhadap profitabilitas perusahaan.

$\mathrm{H}_{\mathrm{a} 3}: \beta_{3}>0$ Kepemilikan manajerial berpengaruh positif terhadap profitabilitas perusahaan.

Berdasarkan hasil analisis regresi linier berganda yang telah dilakukan, besarnya profitabilitas koefisien regresi baku variabel kepemilikan manajerial (KM) adalah $\beta_{3}=0,150$ dengan $p=0,008$. Pada tingkat signifikansi $\alpha=0,05$ maka $p(0,008)<\alpha(0,05)$, sehingga koefisien regresi baku $\beta_{3}$ signifikan lebih besar dari nol. Dari hasil tersebut maka hipotesis nol $\left(\mathrm{H}_{\mathrm{o} 3}\right)$ ditolak dan hipotesis alternatif $\left(\mathrm{H}_{\mathrm{a} 3}\right)$ diterima, dengan kata lain hipotesis ketiga penelitian ini diterima. Hasil hipotesis ketiga diterima berarti dapat disimpulkan bahwa kepemilikan manajerial berpengaruh positif terhadap profitabilitas perusahaan. Hasil ini tidak mendukung penelitian yang dilakukan oleh Wiranata dan Nugrahanti (2013), tetapi mendukung penelitian sebelumnya yang telah dilakukan oleh Wahyudi dan Pawestri (2006) serta Permanasari (2010).

\section{Pembahasan}

Struktur modal perusahaan yang merupakan rasio atau perbandingan antara total liabilitas dengan modal sendiri perusahaan yang digunakan untuk menjalankan kegiatan operasional, dalam penelitian ini terbukti memiliki pengaruh yang signifikan dan positif terhadap profitabilitas perusahaan. Artinya, semakin tinggi struktur modal maka perusahaan cenderung memperoleh laba yang tinggi atau profitabilitas yang tinggi. Hal ini dapat terjadi selama penggunaan liabilitas tersebut digunakan untuk mendukung proses produksi. Hasil penelitian ini selaras dengan hasil penelitian yang dilakukan oleh Fauzan dan Mukaram (2017) serta peneltian Kusumajaya (2011).

Hasil pengujian kepemilikan institusional dalam penelitian ini terbukti secara empiris bahwa kepemilikan institusional memiliki pengaruh yang signifikan dan positif terhadap profitabilitas perusahaan. Artinya, semakin meningkat kepemilikan institusional maka profitabilitas yang akan diperoleh perusahaan mempunyai kecenderungan meningkat. Hal ini dikarenakan kepemilikan saham institusional yang semakin besar maka kontrol yang dilakukan semakin kuat, sehingga dapat mencegah tindakan manajemen yang kurang tepat dalam mengelola perusahaan dan pada akhirnya profitabilitas perusahaan akan meningkat seiring dengan meningkatnya produktivitas dari perusahaan. Peningkatan produktivitas dari perusahaan salah satunya dapat dilihat dari kemampuan manajemen menghasilkan profit yang tinggi, apabila profit tinggi akan dapat menjadi sinyal positif bagi pasar dan keadaan tersebut akan meningkatkan 
harga saham perusahaan. Hasil penelitian ini selaras dengan hasil penelitian yang dilakukan oleh Pancawati (2009), Permanasari (2010) dan Gultom dkk. (2013), dimana kepemilikan institusional berpengaruh positif dan signifikan terhadap profitabilitas perusahaan.

Dalam penelitian ini terbukti pula bahwa kepemilikan manajerial berpengaruh positif dan signifikan terhadap profitabilitas perusahaan. Artinya, semakin meningkat kepemilikan manajerial maka profitabilitas yang akan diperoleh perusahaan mempunyai kecenderungan meningkat. Hal ini dikarenakan kepemilikan manajerial merupakan pemegang saham dari pihak manajemen yang secara aktif ikut dalam pengambilan keputusan perusahaan oleh direktur dan komisaris (Satmoko dkk.,2011). Manajer akan berusaha keras untuk meningkatkan profitabilitas perusahaan, profitabilitas meningkat maka apresiasi investor ditunjukkan dengan harga saham yang meningkat di pasar modal, maka keuntungan manajer sebagai individu pemegang saham secara tidak langsung akan meningkat. Hasil penelitian ini selaras dengan hasil penelitian yang dilakukan oleh Wahyudi dan Pawestri (2006) serta permanasari (2010) yang menyatakan bahwa kepemilikan manajerial berpengaruh positif dan signifikan terhadap profitabilitas perusahaan.

\section{E. KESIMPULAN}

Penelitian ini menunjukkan hasil bahwa struktur modal, kepemilikan institusional, dan kepemilikan manajerial berpengaruh positif terhadap profitabilitas. Hal ini menunjukkan jika struktur modal, kepemilikan institusional, dan kepemilikan manajerial semakin tinggi, maka profitabilitas perusahaan cenderung meningkat. Koefisien determinasi adjusted model regresi penelitian ini sebesar 17,8\%. Profitabilitas tersebut mengindikasikan bahwa tinggi rendahnya profitabilitas perusahaan sampel $17,8 \%$ ditentukan oleh struktur modal, kepemilikan institusional dan kepemilikan manajerial; sedangkan $82,2 \%$ sisanya ditentukan oleh variabel-variabel lain yang tidak tercakup dalam model regresi penelitian ini. Penelitian ini tidak terlepas dari keterbatasan. Sampel yang digunakan dari penelitian ini adalah perusahaan manufaktur dimana karakteristik perusahaan ini berbeda dengan perusahaan yang bergerak di bidang keuangan. Penelitian selanjutnya diharapkan menggunakan sampel yang berbeda. Rendahnya Adjusted $R^{2}$ dari model yang diuji dalam penelitian ini menunjukkan bahwa variabel lain yang tidak digunakan dalam variabel penelitian ini mungkin mempunyai pengaruh yang lebih besar terhadap profitabilitas perusahaan manufaktur di Indonesia.

\section{DAFTAR PUSTAKA}

Ang, Robert. 1997. Buku Pintar Pasar Modal Indonesia. (The Intelegent Guide toIndonesia Capital Market). Mediasoft Indonesia. Jakarta.

Belkaoui, Ahmed R. 2007. Accounting Theory. Buku 2. Jakarta : Salemba Empat. 


\section{Sapto Bayu Aji, Djasmanuddin, Andriono}

Brigham, E.F. dan Houston, J.F. 2001. Dasar-Dasar Manajemen Keuangan. Erlangga, Jakarta.

Brigham, E. F. dan J. F. Houston. 2008. Dasar-dasar Manajemen Keuangan buku 2.(AlihBahasa : Ali Akbar Yulianto). Jakarta : Salemba Empat.

Chen, R. Carl, dan Steiner, T.L. 1999. Managerial Ownership and Agency Conflict : A Nonlinear Simultaneous Equation Analysis of Managerial Ownership, Risk Taking, Debt Policy and Dividend Policy, FinancialReview, Vol. 34, pp. 119137.

Christianti, A. 2006. Penentuan Perilaku Kebijakan Struktur Modal pada Perusahaan Manufaktur di Bursa Efek Jakarta. Simposium Nasional Akuntasi (SNA) IX, Padang, 23-26 Agustus 2006.

Fauzan, M.R., dan Mukaram. 2017. Pengaruh Struktur Modal terhadap Profitabilitas. Jurnal Riset Bisnis \& Investasi. Vol. 3, No. 3.

Fuerst, Oren dan Kang-Sok, Hyon. 2000, Corporate Governance Expected Operating Performance, and Pricing, Working Papers; Yale School ofManagement, pp. $1-138$.

Gultom, R., Agustina, dan Wijaya, S.W. 2013. Analisis Faktor-Faktor yang Mempengaruhi Nilai Perusahaan pada Perusahaan Farmasi di Bursa Efek Indonesia. Jurnal Wira Ekonomi Mikroskil, Vol. 3 No. 01, hlm. 51-60.

Hanafi, M. dan Halim, A. 2000.Analisis Laporan Keuangan.Yogyakarta: UPP AMP YKPN.

Hartono. 2005. "Hubungan Teori Signalling dengan Underpricing Saham Perdana diBursa Efek Jakarta”, Jurnal Bisnis dan Manajemen : pp. 35-48.

Horne, J. C. dan J. M. Wachowicz. 2007. Prinsip-Prinsip Manajemen Keuangan. Buku Dua.Edisi Keduabelas. Jakarta: Salemba Empat.

Husnan, S. 2000. Manajemen Keuangan. Yogyakarta: Yogyakarta: UPP AMP YKPN.

Ismiyanti, Fitri dan Mamduh, M. Hanafi. 2004. "Struktur Kepemilikan, Risiko, dan Kebijakan Keuangan: Analisis Persamaan Simultan”. Jurnal Ekonomidan Bisnis Indonesia, Vol 19, No 2, 176-196.

Iturriaga, F. J.L. dan Sanz, J. A. R. 1998. Ownership Structure, Corporate Value and Firm Investment: a Spanish Firms Simulataneous Equations Analysis. Working Paper Universidad de Valladolid, Approach, Bell Journal ofEconomics, Vol. 8 No. 1, p. 319- 32.

Jama'an. 2008. Pengaruh Mekanisme Corporate Governance, dan Kualitas Kantor Akuntan Publik Terhadap Integritas Informasi Laporan Keuangan (Studi Kasus Perusahaan publik yang Listing di BEJ). Semarang: Universitas Diponegoro. 
Jensen, M.C. dan Meckling, W.H. 1976. Theory of the Firm : Managerial Behavior, Agency Costs and Ownership Structure . Journal of Financial Economics, Oktober, 1976, V. 3, No. 4, pp. 305-360. Avalaible from: audit Delay, Vol.10, No.3, pp.109-121.

Kusumajaya, D.K.O. 2011. Pengaruh Struktur Modal dan Pertumbuhan Perusahaan Terhadap Profitabilitas dan Nilai Perusahaan. Tesis Program Pasca Sarjana Universitas Udayana.

Kusumastuti, Sari, Supatmi, dan Perdana, Sastra. 2005. Pengaruh Board Diversity terhadap Nilai Perusahaan dalam Perspektif Corporate Governance. Jurnal Ekonomi dan Keuangan. Vol 9. No.2, pp. 88-98.

Martono dan Harjito, A. 2005. Manajemen Keuangan. Yogyakarta: Penerbit Ekonisia, FE UII.

Na'im, Ainun. 1999. Nilai Informasi Ketepatan Waktu Penyampaian Laporan Keuangan: Analisis Empirik Regulasi Informasi di Indonesia. Jurnal Ekonomi \& Bisnis Indonesia. Vol. 14, No. 2, pp. 85-100.

Pancawati, H. 2009. Determinan Nilai Perusahaan. JAI Vol.5, No.2, pp. 231-250.

Permanasari, W.I. (2010). Pengaruh Kepemilikan Manajemen, Kepemilikan Perusahaan. Skripsi. Universitas Diponegoro.

Petronila T.A dan Mukhlasin. 2003. Pengaruh Profitabilitas Perusahaan Terhadap Ketepatan Waktu Pelaporan Keuangan dengan Opini Audit Sebagai Moderating Variabel, Jurnal Ekonomi dan Bisnis PP. 17-26 pp. 1-32.

Rachmawati, Andri dan Triatmoko, Hanung. 2007. Analisis Faktor-Faktor yang Memengaruhi Kualitas Laba dan Nilai Perusahaan. Disampaikan pada Simposium Nasional Akuntansi (SNA) X Makassar.

Riyanto, B. (2001). Dasar-dasar Pembelanjaan Perusahaan. Yogyakarta: BPFE Universitas Gajah Mada.

Rosalia, Wanda dan Budiyanto. 2018. Pengaruh Struktur Modal Terhadap Profitabilitas Pada Perusahaan Manufaktur Sub Sektor Food and Beverages Yang Terdaftar di BEI. Jurnal Ilmu dan Riset Manajemen. Vol. 7, No. 4.

Ross, S. 1977. The Determination of Financial Structure: the Icentive Signalling Approach, Bell Jounal Of Economics, 8, 23-40.

Satmoko, Agung dan Sudarman. 2011. Impact of Personal Taxes on Corporate Dividend Policy and Capital Structure Decisions, Finance Management. Financial Management Association. 19 (2), pp. 21-31.

Siallagan, Hamonangan dan Machfoedz, M. 2006. Mekanisme Corporate Governance, 


\section{Sapto Bayu Aji, Djasmanuddin, Andriono}

Kualitas Laba dan Nilai Perusahaan. Disampaikan pada Simposium Nasional Akuntansi (SNA) IX Padang.

Singh', N.P. dan Bagga', M. 2019. The Effect of Capital Structure on Profitability. Jindal Journal of Bussiness Research. 8(1) 65-77.

Sitepu, Citra Noveli. 2010. Pengaruh Kinerja Keuangan Terhadap Harga Saham pada Perusahaan Industri Makanan dan Minuman yang terdaftar di BEI, Jurnal Akuntansi, Universtias Sumatera Utara fakultas Ekonomi Medan.

Slovin, Myron B. dan Sushka, Merie E. 1993. Ownership Concentration, Corporate Control Activity, and Firm Value: Evidence from The Death ofInside Block holder. Journal of Finance; Vol. XLVII, No. 4.

Sujono dan Soebiantoro, Ugy. 2007. Pengaruh Struktur Kepemilikan Saham, Leverage, Faktor Intern dan Faktor Ekstern Terhadap Nilai Perusahaan (Studi empirik pada perusahaan manufaktur dan non manufaktur di Bursa Efek Jakarta). Jurnal Manajemen dan Kewirausahaan, 9(1),pp. 43-47.

Suwardjono. 2005. Teori Akuntansi: Perekayasaan Pelaporan Keuangan (Edisi III). Yogyakarta: BPFE.

Tambunan, B.H. 2015. Pengaruh Struktur Modal terhadap Nilai Perusahaan. Jurnal Ilmiah “Dunia Ilmu”. Vol. 1 No. 1, hlm. 1-9.

Wahyudi, Untung dan Pawestri, H.P. 2006. Implikasi Struktur Kepemilikan Terhadap Nilai Perusahaan: Dengan Keputusan Keuangan Sebagai Variabel Intervening. Disampaikan pada Simposium Nasional Akuntansi (SNA) IX Padang.

Weston, F. dan Copeland. 2010. Manajemen Keuangan. Jakarta: Erlangga.

Widarjono, 2007. Ekonometrika. BP FE UII, Yogyakarta.

Winarto , J. 2015. The Determinants of Manufacturer Firm Value in Indonesia Stock Exchange. International Journal of Information, Business and Management, Vol. 7, No.4, pp. 323-349.

Wiranata, YA. dan Nugrahanti, Y. 2013. Pengaruh Struktur Kepemilikan Terhadap Profitabilitas Perusahaan Manufaktur di Indonesia. Jurnal Akuntansi dan Keuangan. Vol. 15, No. 1, hlm. 15-26.

Wolk, Harry, Michael G. Tearney, dan James L Dodd. 2000. Accounting Theory: A Conceptual and Institutional Approach. South-Western CollegePublishing. 